\title{
Diallel Analysis for Morphological and Biochemical Traits in Tomato Cultivated under the Influence of Tomato Leaf Curl Virus
}

\author{
Prashant Kaushik $^{1, *}$ and Major Singh Dhaliwal ${ }^{2}$ \\ 1 Instituto de Conservación y Mejora de la Agrodiversidad Valenciana, Universitat Politècnica de València, \\ 46022 Valencia, Spain \\ 2 Department of Vegetable Science, Punjab Agricultural University, Ludhiana 141004, India; \\ msdhaliwal@pau.edu \\ * Correspondence: prakau@doctor.upv.es; Tel.: +34-9638-77000
}

Received: 18 July 2018; Accepted: 17 August 2018; Published: 19 August 2018

\begin{abstract}
Eloquent information about the genetic basis of inheritance is important for any breeding program. Therefore, a diallel study was conducted under the influence of tomato leaf curl virus (TLCV) disease, using the eleven advanced lines of tomato. Firstly, information regarding percent disease index (PDI) was determined via artificial screening with viruliferous whiteflies. Later, these lines were crossed in a half diallel mating design to produce fifty-five one-way hybrids. These hybrids and parental genotypes were evaluated for morphological and biochemical traits under open field conditions. Using the Griffing approach (Method II and Model I), the basis of the inheritance of traits was determined. Furthermore, a Bayesian model was applied to the total yield descriptor. Correlation data indicated that total yield was not correlated with any other trait. The significant general combining ability (GCA) and specific combining ability (SCA) values indicate exploitable genetic variation. The broad-sense heritability values were larger than narrow-sense heritability, showing that selection will be efficient for the improvement of these traits. Hybrid combinations $\mathrm{H} 23$, $\mathrm{H} 42$ and $\mathrm{H} 49$ can be considered efficient for the selection of multiple traits, including yield. Overall, this study provides useful information regarding the genetics of important traits of tomato under TLCV infestation.
\end{abstract}

Keywords: tomato; TLCV; combining ability; resistance breeding; hybrid development; diallel analysis; Griffing approach; Bayesian

\section{Introduction}

Tomato (Solanum lycopersicum L.) is among the most cultivated plants; hence, the efforts toward its genetic improvement date back to the last century and are still enduring through traditional breeding and genomics-based approaches [1,2]. Tomatoes are well acclimatized and bred to yield under extreme climatic conditions like drought and frost [3-5]. However, insect pests and diseases are still big challenges for the successful production of tomatoes. Worldwide, approximately around 146 viruses belonging to 33 different genera are reported to infect tomato plant [6,7]. Among them, the genus Begomovirus causes huge economic losses to tomato production. Belonging to this genus, a DNA virus known as the tomato leaf curl virus (TLCV) is a serious disease of tomato, and its incidence can easily result in up to a 90 percent yield loss of the tomato crop [8,9].

Tomato production especially of the autumn season crop in Northern India and the summer season crop of Southern India is susceptible to a high incidence of tomato leaf curl virus (TLCV) disease [10]. TLCV is transmitted by whitefly (Bemisia tabaci Genn.) in a circulative and persistent manner [11]. Hitherto, in North India, tomato leaf curl New Delhi virus, a strain of TLCV reported from 
the New Delhi region of India, has an extensive distribution and also infects several other vegetable crops, e.g., eggplant, squash and pepper [12]. As a response to TLCV infection, plant leaves shows symptoms like curling of leaf margins, shrinking and thickening of the leaf surface, while the overall plant becomes stunted in growth, with few and misshaped fruits [11]. Extensive efforts in the form of phenotypic screening have been made in order to identify resistant genotypes. In this respect, artificial cage inoculation using viruliferous whiteflies is the most competent and reliable method to carry out the screening for TLCV disease. However, with artificial screening, the plant gives a stronger reaction response than it might give under the field conditions [13,14].

Tomatoes are an important source of nutraceuticals like vitamins (C, K, B6, etc.), phenolic acids and minerals (folate, manganese, etc.). All of these are vital for human health and body development $[15,16]$. Particularly, its fruits contain one of the important dietary carotenoids, known as lycopene, important for the prevention of chronic diseases like breast, lung and prostate cancer [17-19]. The lycopene content $\left(\mathrm{mg} 100^{-1} \mathrm{~g}\right)$ of tomato varies based on genotypes' genetic makeup, cultivation environment, disease pressure and genotype-by-environment interactions [20]. The nutraceutical properties of tomato fruit have industrialized the processing of tomatoes; commonly, tomatoes are processed as juice, ketchup, paste and sauce [21]. These biochemical aspects of the tomato fruit have become an important goal of tomato breeding programs [22,23].

Hybrid development is a successful approach for vegetable improvement, especially for solanaceous vegetables. Furthermore, to chalk out a breeding strategy for successful cultivation under TLCV infestation, it is important to have information about the inheritance of traits under the prevailing conditions. Therefore, estimation general combining ability (GCA) and the specific combining ability (SCA) are important for genetic enhancement of the crop. However, the amount of variation in GCA and SCA values does not totally rest on gene effects; it also involves the gene structure of the parents involved [24]. Diallel mating design based on the general linear model framed by Griffing [25] is a popular choice and widely-accepted tool for the identification of the hybrid combinations of interest in tomato and in other members of Solanaceae [26-28]. Previously, studies indicated that leaf characteristics and foliar pubescence affect the feeding preferences of whiteflies [29,30]. Sometimes, Griffing's method is not adequate in the case of missing data, imbalance and outliers under the situations where chances of bias are too high to avoid. This is especially true with experiments carried out under disease pressure conditions [31,32].

The use of more rigorous Bayesian methods overcomes these limitations [33,34]. The BayesDiallel approach uses a Markov chain Monte Carlo (MCMC) sampling distribution, which in turn provides greater flexibility, which further improves the biological interpretability of the results. Therefore, in this study, the parameter of the total yield $\left(\mathrm{kg} \mathrm{plant}^{-1}\right)$ was investigated with this Bayesian approach. The Bayesian approach is not popular among the plant breeding community because of calculation limitations and the complexity of the statistics involved [35]. However, the different models based on the Bayesian approach provide a more vigorous and detailed analysis of highly variable and complex traits like yield. Acquaintance with the genetics of important morphological traits under tomato leaf curl virus infestation conditions will be helpful for carrying out efficient selection and breeding.

Therefore, the objectives of this study were to determine the GCA, SCA and heritability of tomato genotypes crossed in a half diallel mating design. Further, the BayesDiallel approach was used to provide a more comprehensive analysis of diallel data generated for the total yield. By applying the BayesDiallel approach the first time on the total yield data of the diallel cross under TLCV conditions along with Griffing's method, we aim to estimate the combining ability and the heritability estimates precisely and to suggest a robust approach aimed at tomato TLCV resistance breeding. 


\section{Materials and Methods}

\subsection{Plant Material and Artificial Screening}

Eleven advanced lines of tomato developed at the Punjab Agricultural University (coordinates at $30^{\circ} 54^{\prime} 14.8856^{\prime \prime} \mathrm{N} 75^{\circ} 49^{\prime} 0.4822^{\prime \prime} \mathrm{E}$ ), Ludhiana, India, were artificially screened for resistance to TLCV disease during 2011-2012. The artificial screening of seedlings ( 2-3 week old) was carried out by challenging 25 plants of each of the eleven genotypes with viruliferous whiteflies reared on the TLCV disease-affected plant; the detailed method is provided elsewhere [26]. The disease reaction of genotypes was scored on the scale, where $0 \%-10 \%$ is resistant $(\mathrm{R}),>10 \%-30 \%$ moderately resistant (MR), $>30 \%-70 \%$ susceptible (S) and $>70 \%-100 \%$ highly susceptible (HS) [36,37]. Further, the potential disease incidence (PDI) was measured as the (number of infected plants/total number of plants) $\times 100$. The eleven genotypes were crossed in a diallel mating design during February-March 2012, resulting in fifty-five one way $\mathrm{F}_{1}$ hybrids. Thereafter, for the first cross combination, $\mathrm{H} 1$ is referred to as the first cross in the half diallel, i.e., H1 $(\mathrm{P} 1 \times \mathrm{P} 2)$, and so on, until the last cross as H55 (P10 × P11) (Table 1). The 11 parental genotypes and 55 one-way hybrids were evaluated under the whitefly infestation conditions during August 2012 in a randomized complete block design. Each entry was replicated twice, and each replication accommodated 15 plants. Plant production practices were exercised as per the Package of Practices, and no chemical treatment was used to control the whiteflies. Data were recorded on 13 central plants leaving one plant on either side of the row.

Table 1. Representation of the cross or hybrid combinations (55 in total) developed as a result of the half-diallel mating design.

\begin{tabular}{lcccccccccc}
\hline & P2 & P3 & P4 & P5 & P6 & P7 & P8 & P9 & P10 & P11 \\
\hline P1 & H1 & H2 & H3 & H4 & H5 & H6 & H7 & H8 & H9 & H10 \\
P2 & & H11 & H12 & H13 & H14 & H15 & H16 & H17 & H18 & H19 \\
P3 & & & H20 & H21 & H22 & H23 & H24 & H25 & H26 & H27 \\
P4 & & & & H28 & H29 & H30 & H31 & H32 & H33 & H34 \\
P5 & & & & & H35 & H36 & H37 & H38 & H39 & H40 \\
P6 & & & & & & H41 & H42 & H43 & H44 & H45 \\
P7 & & & & & & & H46 & H47 & H48 & H49 \\
P8 & & & & & & & & H50 & H51 & H52 \\
P9 & & & & & & & & H53 & H54 \\
P10 & & & & & & & & & & H55 \\
P11 & & & & & & & & & \\
\hline
\end{tabular}

\subsection{Characterization and Data Analysis}

Total yield ( $\left.\mathrm{kg} \mathrm{plant}^{-1}\right)$ and marketable yield $\left(\mathrm{kg} \mathrm{plant}^{-1}\right)$ were determined on a per plant basis, i.e., by dividing the harvest by the number of plants. Fruit weight (g) was estimated as the average weight per fruit of the ten-fruit sample collected at the red ripe stage. Five fruits per replication were used to measure the equatorial diameter, locules, pericarp thickness and polar diameter. The polar diameter of cut fruits was measured as the distance between the stalk end and the blossom end. Conversely, the equatorial diameter was measured as the transversal distance of the fruit. Locules were determined as the separate cavities identified in the fruit after opening it horizontally. Pericarp thickness was measured from the center of the fruit. These fruit-based morphometric measurements were recorded with the help of the Vernier caliper.

Three biochemical parameters were estimated included dry matter, lycopene and total soluble solids (TSS) using three samples for each replication. Each sample was constituted of five red ripe fruits. Dry matter percentage was measured as the change of weight before and after oven drying at $70{ }^{\circ} \mathrm{C}$ and was calculated based on the formula $100 \times$ (dry weight/fresh weight). TSS content of fruits was determined with the help of a hand refractometer (RA-130-KEM, Kyoto Electronics Manufacturing Co., Ltd., Kyoto, Japan). The readings were recorded as Brix $\left(0-32^{\circ} \mathrm{C}\right)$ at room temperature. Lycopene 
content was determined by the method suggested elsewhere [38]. The optical densities of processed extracts for the lycopene content were recorded at 505 nanometers $(\mathrm{nm})$ using Spectronic 20 (Thermo Fisher Scientific, Waltham, MA, USA). The combining abilities were estimated based on Griffing's Method II (parental genotypes and one-way hybrids) with Model I (fixed effect) [25]. The diallel calculations were performed with the help of the package AGD-R (analysis of genetic designs with the $R$ software package) Version 4.0 [39]. Baker's ratio was estimated using the formula, Baker ratio $=2 \mathrm{MSGCA} / 2 \mathrm{MSGCA}+$ MSSCA [35]. Pearson coefficients of correlation $(r)$ and their $p$-values were calculated and plotted using the package corrplot [40]. The chart. Correlation $(r)$ function within the PerformanceAnalytics package was used to generate scatter plots and histograms along with detailed information regarding correlations [41].

\subsection{Bayesian Model-Based Analysis of Total Yield}

The R package BayesDiallel was used for the Bayesian model-based analysis of total yield data [34]. Briefly, we used the "Bab" model in the BayesDiallel package; this model includes an overall effect of being inbred (B), which is a fixed effect that captures an additive component (a), and a measure of parent-specific inbred deviation (b), which is any additional deviation of an inbred parent from the $F_{1}$ hybrids that is not captured by the fixed effect ' $\mathrm{B}$ '. Also, the "Bab" model was applied using an MCMC Gibbs sampler with five chains, 10,000 iterations and a burn-in of 1000 [35]. The model is based on the following equation:

$$
\boldsymbol{y}_{i}=\mu+\text { mother }_{j[i]}+\text { father }_{k[i]}+\text { pair }_{(j k)[i]}+\varepsilon_{i}
$$

where $\operatorname{pair}_{(j k)[i]}$ is a deviation specific to the mother-father $\operatorname{pair}_{(j k)}$.

In the "Bab" model, this pair is calculated as a strain-specific inbred penalty $b_{j} \beta_{\text {inbred}}$; i.e., $\beta_{\text {inbred }}$ :

$$
\operatorname{pair}_{(j k)}=I_{(j=k)}+\left(b_{j}+\beta_{\text {inbred }}\right)_{(\mathrm{a})} b_{j} \sim \mathrm{N}\left(0, \tau_{\mathrm{b}}^{2}\right)
$$

where $\tau_{\mathrm{b}}^{2}=0$ implies a constant inbred penalty [34].

\section{Results and Discussion}

\subsection{Artificial Screening}

Artificial screening with viruliferous whiteflies provided a dissimilar percent of disease incidence (PDI) values for each genotype (Figure 1). The 6minimum PDI\% was recorded in P4 (29.2\%, MR), whereas the maximum was recorded with the P1 $(100 \%$, HS) (Figure 1). All eleven parental genotypes exhibited TLCV symptoms after 60 days of artificial inoculation with viruliferous whiteflies. On the TLCV disease scale, two lines showed mild resistance (MR); in contrast, three were highly susceptible (HS), while the rest were susceptible (Figure 1). Under field conditions, parents and hybrids showed a wide variation in the PDI values (Figure 2). In the case of parents, PDI ranged from $7.0 \%-100 \%$; whereas, for hybrids, the PDI percentage ranged from $5.4 \%-85.6 \%$. Furthermore, twelve hybrids showed less than $10 \%$ (R) of PDI (Figure 2).

Earlier studies have shown that as compared to a natural field environment screening of genotypes for TLCV, artificial screening is more useful as it ensures a uniform disease infection and leaves few chances for a susceptible plant to escape infection due to non-preference and loss of whiteflies' infectivity. However, $100 \%$ disease incidence is also common with the artificial inoculation method [13,42]. The artificial screening method using whiteflies is commonly applied to find out the reaction of tomato lines to TLCV disease [43-45]. Previously, the cultivated accessions and the landraces of tomato exhibited a varying range of the disease symptoms, but lacked complete resistance [46]. However, wild relatives of tomato, e.g., S. chmielewskii, S. habrochaites and S. pimpinellifolium, were found resistant even with artificial screening [14]. The differences in the results of the field-based 
screening method could also be due to the difference in virus strain, vector genotype or altered feeding conditions $[47,48]$.

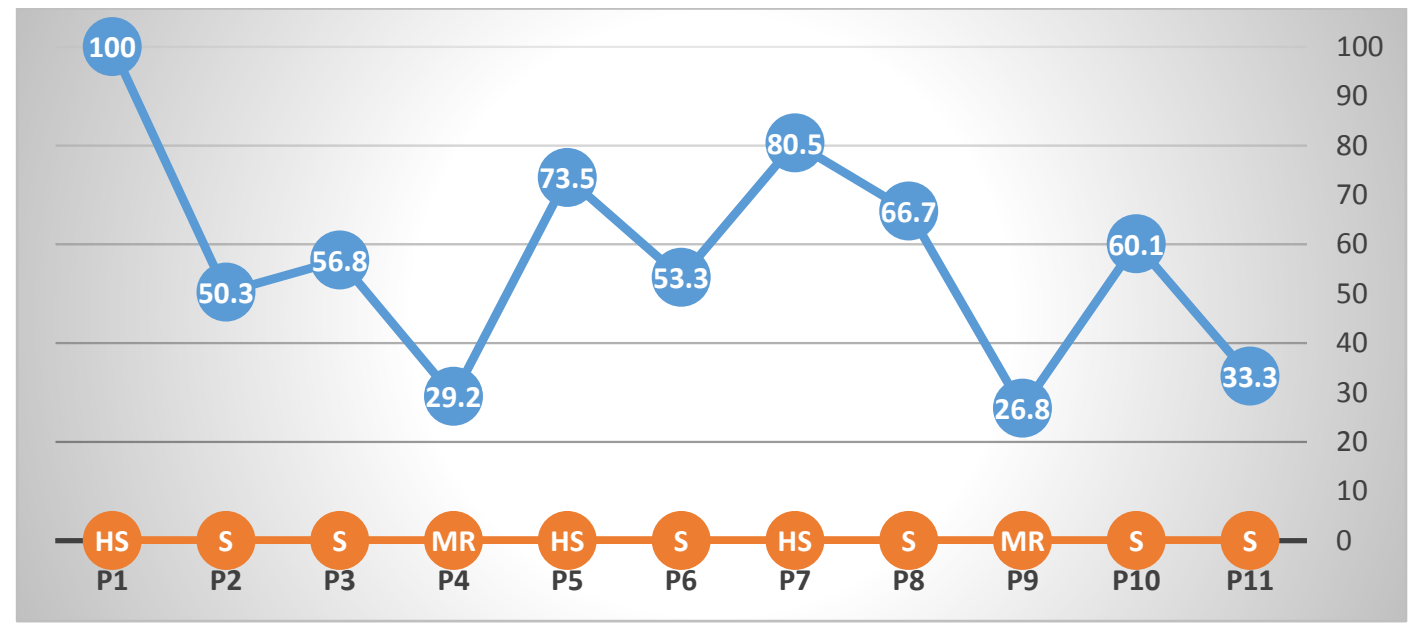

Figure 1. The percent disease incidence (PDI) reaction of parents to TLCV along with the grading scale ( $x$-axis), where HS = Highly Susceptible, MR = Moderately Resistant and S = Susceptible.

\subsection{Variation in Parents and Hybrids}

The mean performance of parents and their hybrids for all studied characteristics is provided in Table S1. The magnitude of the mean squares of genotypes indicated that there were significant differences among the genotypes for all morphological characteristics studied, pointing out the presence of genetic variability (Table 2). Similarly, significant GCA and SCA effects for all measured traits were detected $(p \leq 0.01)$. The lowest value of the Baker ratio was noted for polar diameter (0.56); while the highest was recorded for the fruit weight (0.90) (Table 2). This indicated that the non-additive gene effects were more prevalent for the characteristics under investigation. In general, the GCA variance was higher than that of SCA variance for the characteristics studied. The broad-sense heritability values were higher (above 0.9) than the narrow-sense heritability (below 0.4) (Table 2).

Table 2. Analysis of variance for general combining ability (GCA) and specific combining ability (SCA) for the ten descriptors in tomato under leaf curl virus conditions including the Baker ratio, narrow sense $\left(\mathrm{h}^{2}\right)$ and broad sense heritabilities $\left(\mathrm{H}^{2}\right)$.

\begin{tabular}{|c|c|c|c|c|c|c|c|}
\hline Source of Variation & Genotypes $^{a}$ & $\mathrm{GCA}^{\mathrm{a}}$ & SCA $^{a}$ & Error & Baker Ratio & $\mathrm{h}^{2}$ & $\mathrm{H}^{2}$ \\
\hline Degree of freedom & 65 & 10 & 55 & 65 & & & \\
\hline Dry matter & $0.38^{* * *}$ & $0.66^{* * *}$ & $0.33^{* * *}$ & 0.11 & 0.80 & 0.22 & 0.95 \\
\hline Equatorial diameter & $0.68^{* * *}$ & $0.87^{* * *}$ & $0.65^{* * *}$ & 0.01 & 0.73 & 0.17 & 0.97 \\
\hline Fruit weight & $964.97 * * *$ & $2755.90^{* * *}$ & $639.35^{* * *}$ & 31.90 & 0.90 & 0.38 & 0.94 \\
\hline Locules & $0.87^{* * *}$ & $1.48^{* * *}$ & $0.76^{* * *}$ & 0.02 & 0.80 & 0.22 & 0.96 \\
\hline Lycopene & $1.58^{* * *}$ & $1.91^{* * *}$ & $1.51^{* * *}$ & 0.01 & 0.72 & 0.16 & 0.95 \\
\hline Marketable yield & $0.55^{* * *}$ & $0.71^{* * *}$ & $0.52^{* * *}$ & 0.01 & 0.73 & 0.17 & 0.96 \\
\hline Pericarp thickness & $0.03^{* * *}$ & $0.05^{* * *}$ & $0.03^{* * *}$ & 0.07 & 0.77 & 0.20 & 0.95 \\
\hline Polar diameter & $0.83^{* * *}$ & $0.55^{* * *}$ & $0.88^{* * *}$ & 0.01 & 0.56 & 0.10 & 0.97 \\
\hline Total yield & $0.56^{* * *}$ & $0.91^{* * *}$ & $0.50^{* * *}$ & 0.01 & 0.78 & 0.22 & 0.96 \\
\hline TSS & $0.35^{* * *}$ & $0.28^{* * *}$ & $0.36^{* * *}$ & 0.01 & 0.61 & 0.10 & 0.94 \\
\hline
\end{tabular}




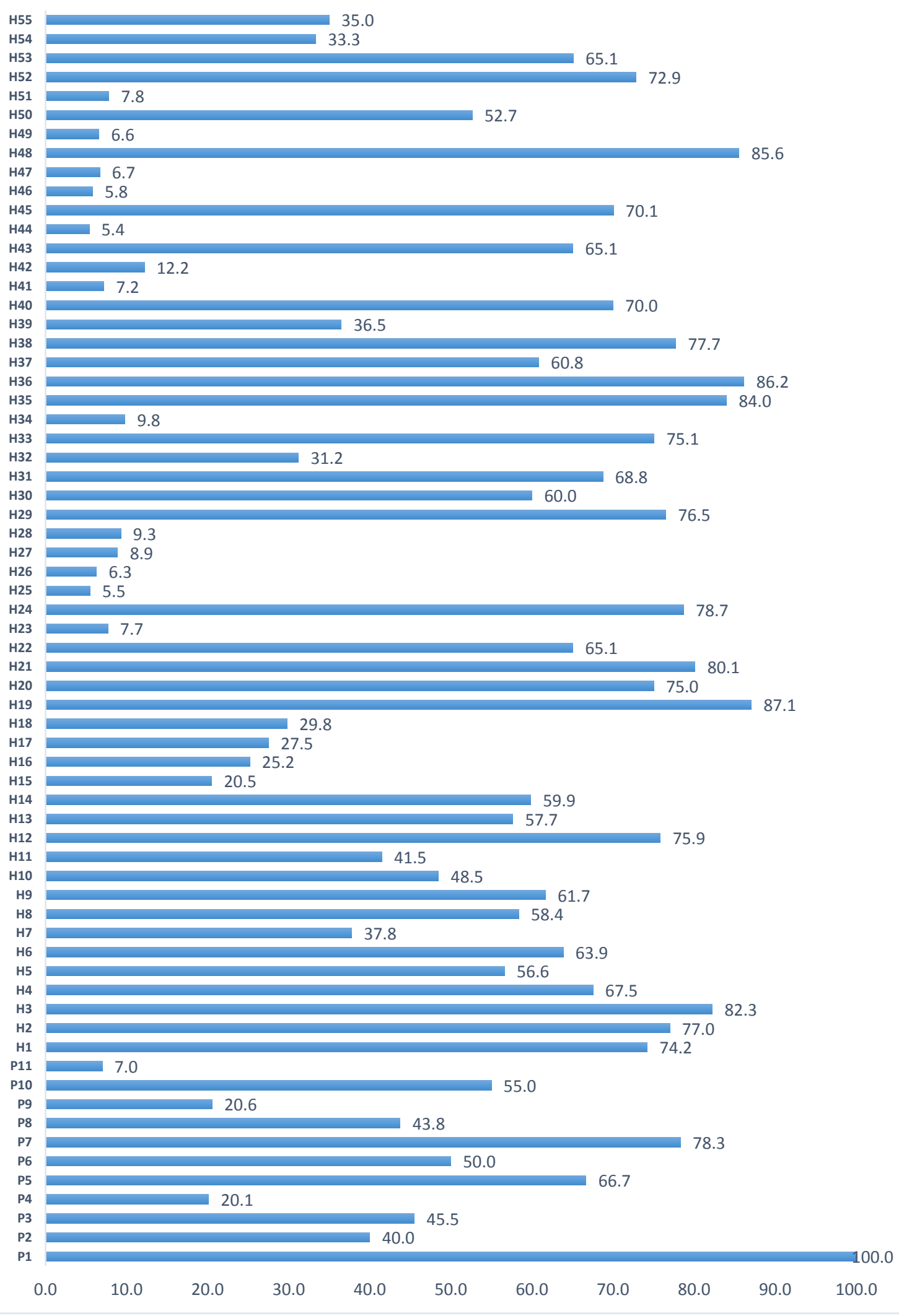

Figure 2. The percent disease incidence (PDI) reaction of parents and the hybrid cross combinations to TLCV infestation under field conditions. 
A higher magnitude of additive gene effects is useful for the development of pure-lines and to proceed with selection $=$ based breeding approaches. Non-additive gene effects are used for the development of hybrids. In previous studies, the presence of both additive and non-additive gene action was reported for most of the characteristics studied in tomato. For example, additive gene action was reported to control yield and its component traits in tomato [49,50]. In contrast, non-additive gene action was reported to control many traits in tomato [51,52]. Similarly, the additive and the non-additive inheritance of biochemical traits like dry matter, lycopene and TSS were also reported [53,54].

\subsection{Bayesian Model-Based Estimates and Predictions of Total Yield}

Both GCA and SCA contributed to the total yield, showing that both additive and non-additive effects were significant. However, GCA values for the total yield were higher than the SCA values (Table 2). The predicted means further revealed this with the BayesDiallel Bab model (Figure 3).
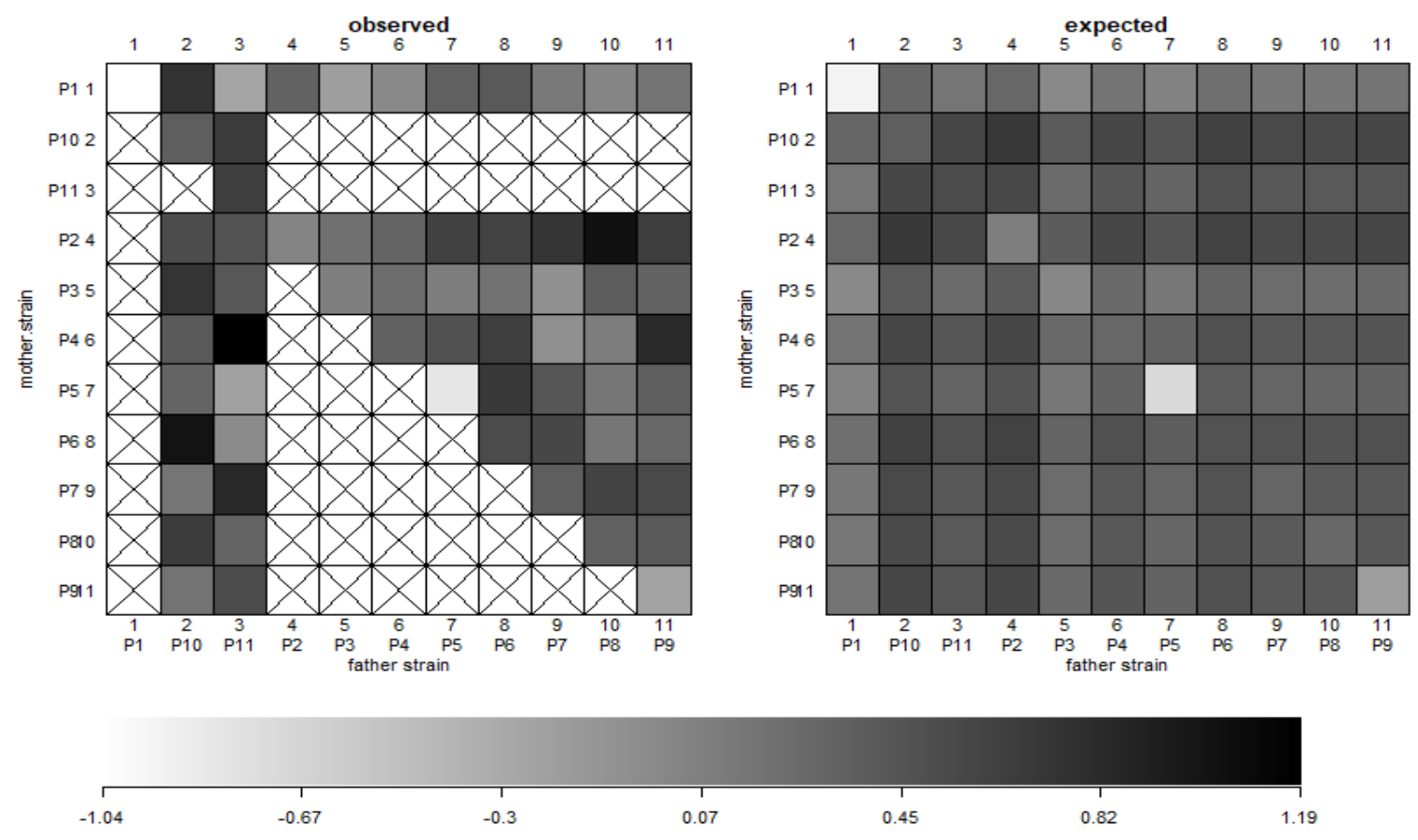

Figure 3. Total yield data of 55 hybrids and 11 parental genotypes in a half diallel. The left is for parental (P1-P11), with crossed boxes indicating the missing data (as half diallel was used) and the shaded box representing the values based on the horizontal scale (below). The right side graph shows predictive means based on the Bab diallel model on the scale of (-1.04-1.19).

The fixed and individual strain additive effects were more stable and less dispersed than the parent of origin and inbreeding effect (Figure 4); justifying a large amount of GCA component identified. The parental genotypes P1, P5 and P9 showed a negative parent of origin and inbreeding effects (Figure 4). The observed vs expected values were found different for some hybrid combinations (Figure 3). This could be attributed to the fact that whiteflies have a preference for some genotypes. The virulence affected the degree, and plant reaction to the disease contributed to such effects $[55,56]$. 


\section{Fixed and Individual Strain \\ Additive Effects}

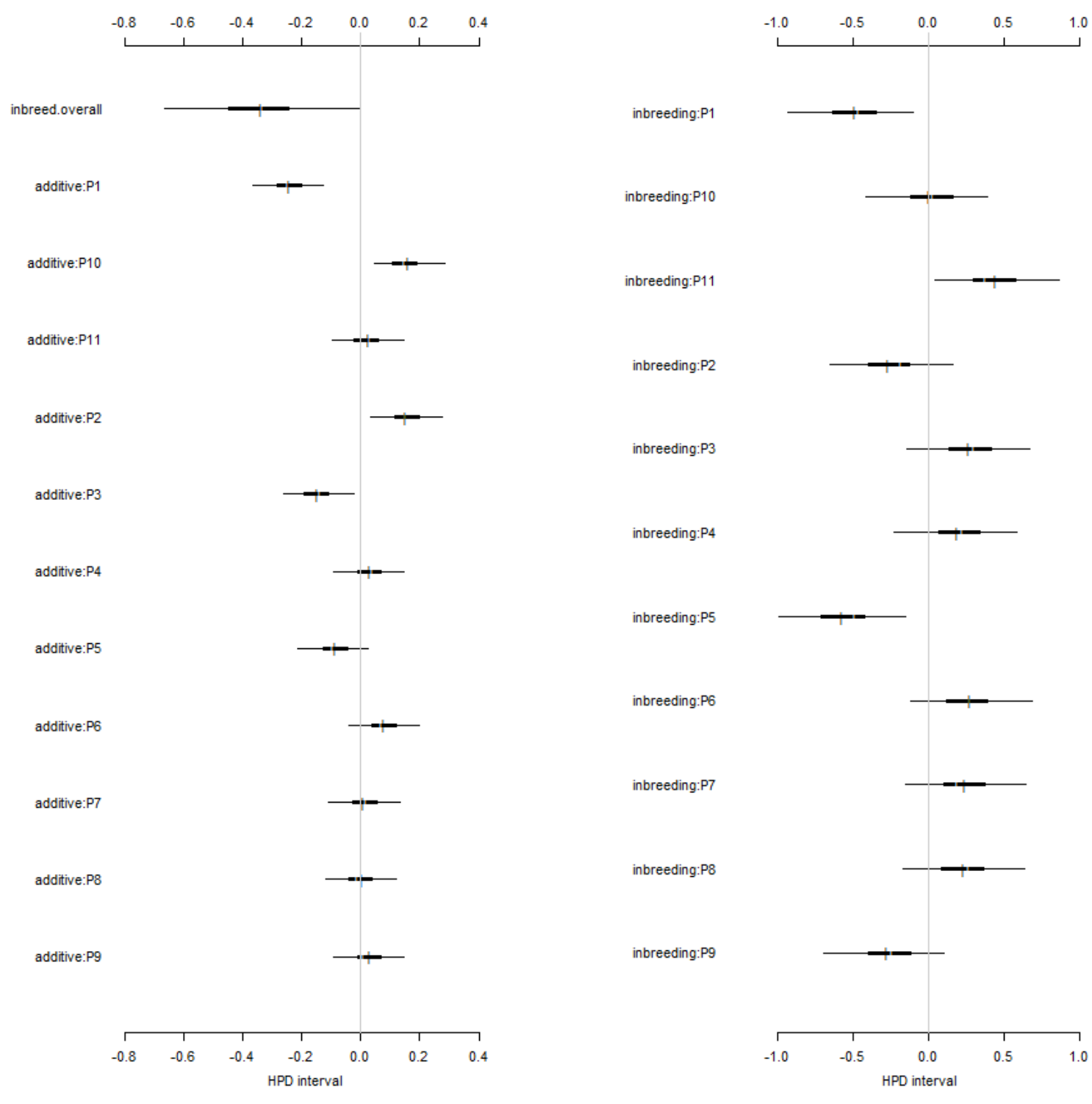

\section{Parent Of Origin and Inbreeding Effects}

Figure 4. Highest posterior density (HDP) intervals of parent-specific additive effects, parent of origin and inbreeding effect of the 11 parents studied.

Likewise, under TLCV disease pressure, the Bayesian approach helped in the determination of heritable and non-heritable components influencing the total yield. This precise determination can be used to determine the most appropriate breeding strategy for maximizing the genetic gain. Overall, this variance projection approach (VarP) is more precise in providing the information about inheritance classes that will affect the future experiments if these eleven parental genotypes are used again [57]. The total yield included the additive effect $(\operatorname{VarP}[\mathrm{a}]=0.24)$, while the effect of non-additive variance was in the form of inbred penalty $(\operatorname{VarP}[\mathrm{B}]=0.07)$, and the noise was 58.97 for the total yield (Figure 5, Table 3). Previously, in the case of cross-pollinated carrots, it was found that the influence of non-additive variation was largely due to the overall inbred penalty (non-additive effects), which contributed significantly to canopy height, shoot biomass and root biomass [35]. 

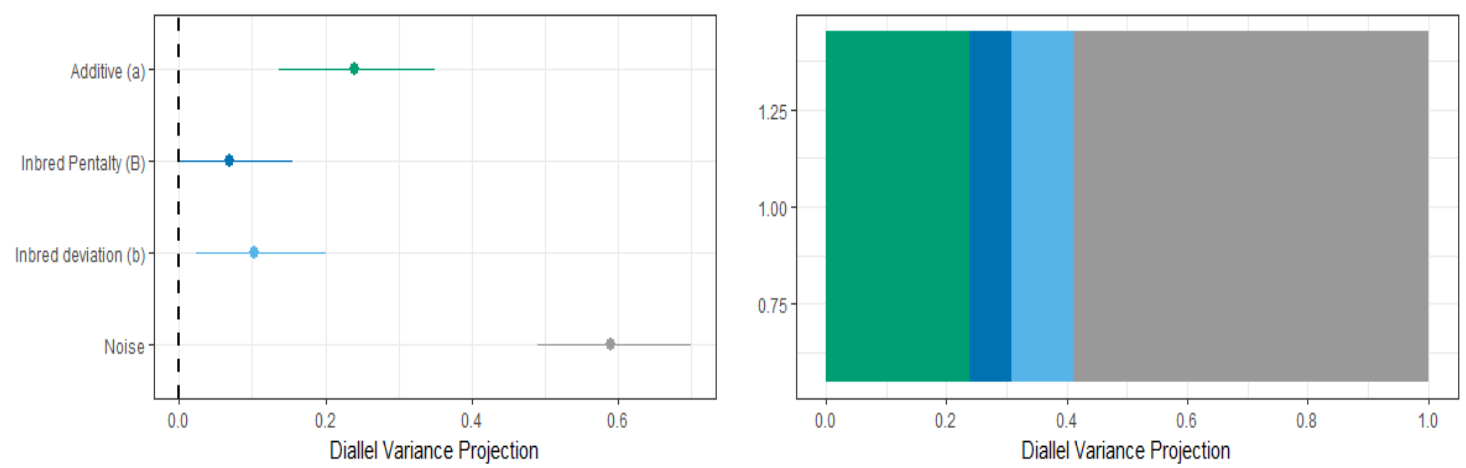

Figure 5. Diallel variance projections of the genetic architecture for total yield.

Table 3. Diallel variance projection approach (VarP) for the tomato total yield trait.

\begin{tabular}{ccccccc}
\hline Diallel Inheritance Class & Mean & $\mathbf{2 . 5 0} \%$ & $\mathbf{2 5 \%}$ & $\mathbf{5 0 \%}$ & $\mathbf{7 5 \%}$ & $\mathbf{9 7 . 5 0 \%}$ \\
\hline Inbred penalty (B) & 6.76 & 0.11 & 4.09 & 6.42 & 9.10 & 15.22 \\
Additive (a) & 23.97 & 13.71 & 20.28 & 23.95 & 27.58 & 34.64 \\
Inbred deviation (b) & 10.31 & 2.33 & 7.09 & 10.03 & 13.16 & 20.25 \\
Total variance explained & 41.03 & 30.31 & 37.45 & 41.18 & 44.72 & 51.15 \\
Unexplained variance & 58.97 & 48.85 & 55.28 & 58.82 & 62.55 & 69.69 \\
\hline
\end{tabular}

\subsection{GCA and SCA Estimates}

Estimates of general combining ability are presented in Table 4. The estimates of GCA were highly significant for all the characteristics studied. P2 expressed the highest GCA effect (0.346) for the dry matter content. For equatorial diameter, $\mathrm{P} 4$ was the best general combiner with the estimates of 0.273 . Regarding fruit weight, P5 (9.596) was the best general combiner followed by P8 (8.453) and P7 (7.770) (Table 4). The genotype with the highest CGA effects for the number of locules is P2 (0.355) followed by P8 (0.350) and P4 (0.261). The genotypes with above average GCA effects for lycopene content included P3 (0.454), P6 (0.427) and P9 (0.213) (Table 4). The highest GCA effects for marketable yield of 0.188 were recorded in genotype P2, followed by P11 and P10. For pericarp thickness, P8 (0.115) had the highest GCA effects. For polar diameter, the highest GCA effects were observed in P7 (0.263); while for total yield, P10 (0.215), P11 (0.164) and P6 (0.154) had high GCA effects. Likewise, the GCA effects of 0.195 and 0.152 were recorded for TSS content in the parents P8 and P1, respectively. 
Table 4. The estimates of general combining ability (GCA) for the parent genotypes (11) for the ten descriptors studied under the influence of leaf curl virus.

\begin{tabular}{|c|c|c|c|c|c|c|c|c|c|c|}
\hline Parent & Dry Matter $^{a}$ & Equatorial Diameter ${ }^{a}$ & Fruit Weight $^{a}$ & Locules $^{a}$ & Lycopene $^{a}$ & Marketable Yield ${ }^{a}$ & Pericarp Thickness ${ }^{a}$ & Polar Diameter $^{\mathrm{a}}$ & Total Yield $^{\mathrm{a}}$ & TSS $^{a}$ \\
\hline P1 & $0.091 * * *$ & $-0.201^{* * *}$ & $-12.458 * * *$ & $-0.022 * * *$ & $-0.121^{* * *}$ & $-0.333^{* * *}$ & $-0.009^{\text {ns }}$ & $0.061 *$ & -0.366 *** & $0.152^{* * *}$ \\
\hline P2 & $0.346^{* * *}$ & $-0.181^{* * *}$ & $6.773^{* * *}$ & $0.355^{* * *}$ & $-0.415^{* * *}$ & $0.188^{* * * *}$ & $0.003^{\mathrm{ns}}$ & $-0.020^{\text {ns }}$ & $0.151^{* * *}$ & $-0.048^{*}$ \\
\hline P3 & $-0.105^{* * *}$ & $-0.098^{* * *}$ & $-15.122^{* * *}$ & $-0.298^{* * *}$ & $0.454^{* * *}$ & $-0.133^{* * *}$ & $-0.007^{\text {ns }}$ & -0.061 * & $-0.206^{* * *}$ & $0.010^{\mathrm{ns}}$ \\
\hline P4 & $-0.121^{* * *}$ & $0.273^{* * *}$ & $8.495^{* * *}$ & $0.261^{* * *}$ & $-0.086^{* *}$ & $0.048^{\text {ns }}$ & $-0.002^{\mathrm{ns}}$ & $0.025^{\text {ns }}$ & $0.089^{* *}$ & $-0.168^{* * *}$ \\
\hline P5 & $-0.067^{* *}$ & $0.137^{* * *}$ & $9.596^{* * *}$ & $-0.085^{* *}$ & $-0.061 *$ & $-0.180^{* * *}$ & $-0.016^{*}$ & $0.177^{* * *}$ & $-0.207^{* * *}$ & $0.034^{\text {ns }}$ \\
\hline P6 & $-0.178^{* * *}$ & $0.041^{\mathrm{ns}}$ & $-0.690^{\mathrm{ns}}$ & $-0.273^{* * *}$ & $0.427 * * *$ & $0.161^{* * *}$ & $-0.038^{* * *}$ & $-0.257^{* * *}$ & $0.154^{* * *}$ & -0.071 ** \\
\hline P7 & $0.021^{\mathrm{ns}}$ & $0.195 * * *$ & $7.770 * * *$ & -0.089 ** & $0.106 * * *$ & $0.012^{\mathrm{ns}}$ & $0.018 *$ & $0.263 * * *$ & $0.032^{\mathrm{ns}}$ & $0.023^{\text {ns }}$ \\
\hline P8 & $0.170^{* * *}$ & $0.168^{* * *}$ & $8.453 * * *$ & $0.350 * * *$ & $-0.169 * * *$ & $0.018^{\text {ns }}$ & $0.115^{* * *}$ & -0.039 ns & $0.023^{\text {ns }}$ & $0.195^{* * *}$ \\
\hline P9 & $0.033^{\text {ns }}$ & $-0.045^{\mathrm{ns}}$ & $4.867^{* * *}$ & $0.126^{* * *}$ & $0.213^{* * *}$ & $-0.070 * *$ & $0.029^{* * *}$ & $-0.178^{* * *}$ & -0.050 * & $-0.011^{\mathrm{ns}}$ \\
\hline P10 & $-0.185^{* * *}$ & $0.007^{\mathrm{ns}}$ & $-0.081^{\text {ns }}$ & $-0.120^{* * *}$ & $-0.215^{* * *}$ & $0.141^{* * *}$ & $-0.035^{* * *}$ & 0.060 * & $0.215^{* * *}$ & $-0.098^{* * *}$ \\
\hline P11 & -0.003 ns & $-0.296^{* * *}$ & $-17.605^{* * *}$ & $-0.205^{* * *}$ & $-0.132 * * *$ & $0.148^{* * * *}$ & $-0.058^{* * *}$ & -0.032 ns & $0.164^{* * *}$ & -0.019 ns \\
\hline
\end{tabular}

a,$* * * * * * *$, ns , indicate significant at $p<0.001, p<0.01, p<0.05$, and nonsignificant, respectively. 
The results of specific combining ability estimates are given in Table S2. The crosses with the highest SCA effects for dry matter content were H22 (1.343), H9 (0.986) and H17 (0.903). The highest SCA effects of 1.386, 1.179 and 1.097 were recorded in the crosses H46, H35 and H23, respectively, for the equatorial diameter. For fruit weight, the highest positive SCA effects were observed in crosses H17 (26.728), H35 (26.639) and H16 (23.633). For locule number, crosses H34, H43 and H46 had the highest SCA effects of 1.551, 1.289 and 1.217, respectively. Similarly, the highest SCA estimates for the lycopene content were recorded in the crosses H30 (1.724), H24 (1.617) and H14 (1.460), in that order. For marketable yield, crosses H49 (1.649), H23 (1.134) and H32 (0.918) recorded the highest SCA values. Likewise, for pericarp thickness, H29 (0.218), H42 (0.166) and H25 (0.140) were significant. Crosses H3 (1.589), H34 (1.283) and H35 (1.005) possessed the highest SCA values for the polar diameter. In the case of total yield, $\mathrm{H} 49, \mathrm{H} 23$ and $\mathrm{H} 42$ with values of 1.539, 1.157 and 0.917 recorded the highest SCA effects, respectively. For the TSS content, crosses with the highest SCA effects included H49 (1.017), H26 (0.961) and $\mathrm{H} 28$ (0.928). Hybrid combinations $\mathrm{H} 23, \mathrm{H} 35, \mathrm{H} 42, \mathrm{H} 46$ and $\mathrm{H} 49$ were found to be good specific combiners for more than one trait (Figure 6). However, none of the hybrids exhibited significant SCA effects for all the traits. The information about the SCA and GCA is crucial for maximizing the genetic gain. These results agree with the results reported in the previous studies under stress and under natural conditions [22,58-60].

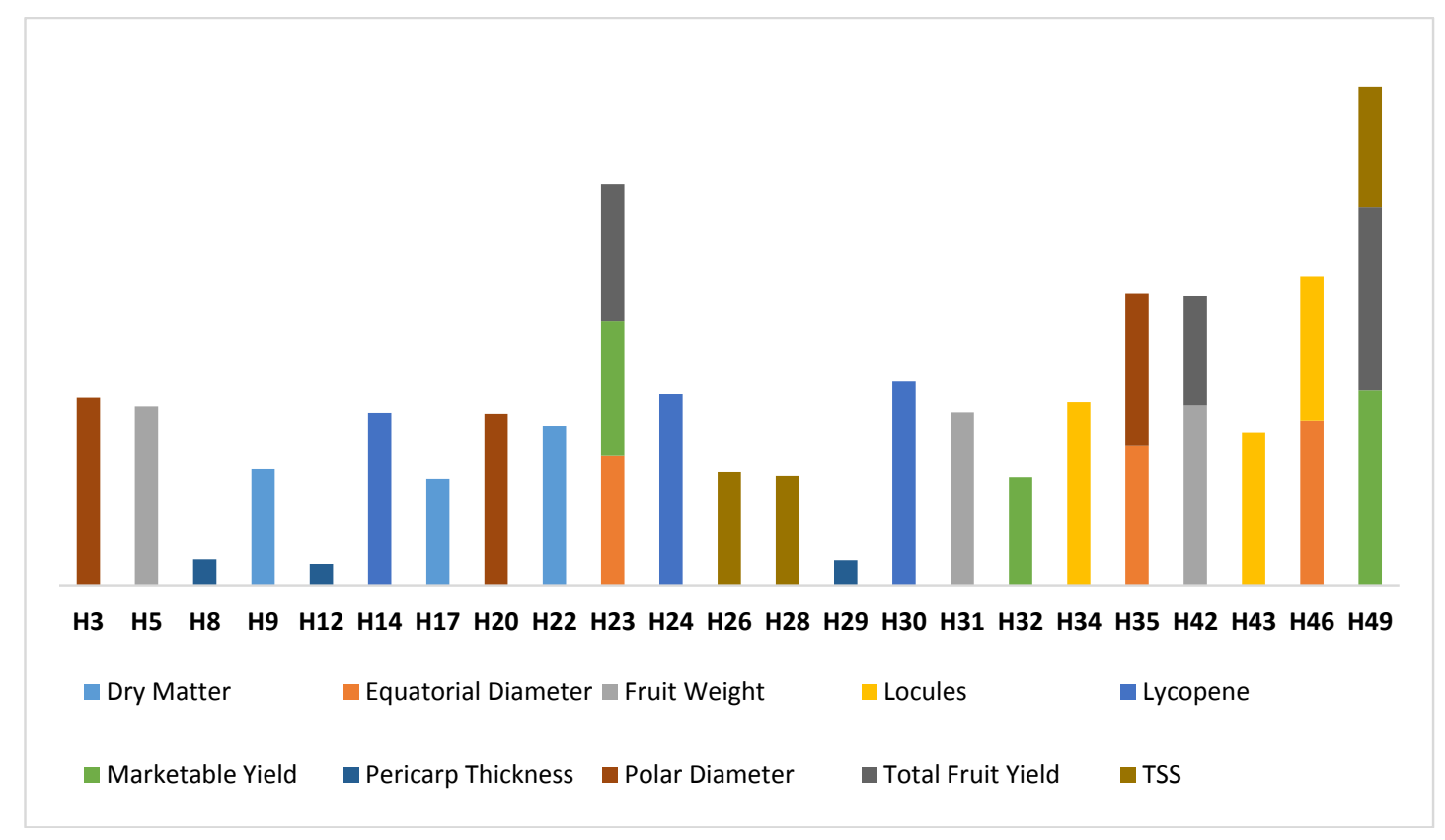

Figure 6. Promising hybrid cross combinations identified based on SCA values, under leaf curl virus infestation.

\subsection{Correlations}

A total of 14 correlations were found to be significant $(p<0.05)$ (Figure 7$)$. One of the correlations was absolute (0.966), that between total yield and marketable yield. Locule number was found to be correlated with fruit weight (0.43), equatorial diameter (0.32), dry matter (0.31) and TSS (0.17); while the fruit weight was correlated with equatorial diameter (0.54), locules (0.43), pericarp thickness (0.28) and polar diameter (0.27). Previous research works conducted on tomato showed similar results. In this direction, a high correlation was noticed between fruit yield, fruit weight and pericarp thickness [61,62]. However, it is worth mentioning that no correlation was found between yield and any of the morphological and biochemical traits. Tomato plant yield under TLCV pressure is independent of any morphological and biochemical trait. Likewise, earlier, it was shown that under salt stress, plants' survival and yield are independent of each other [63]. 


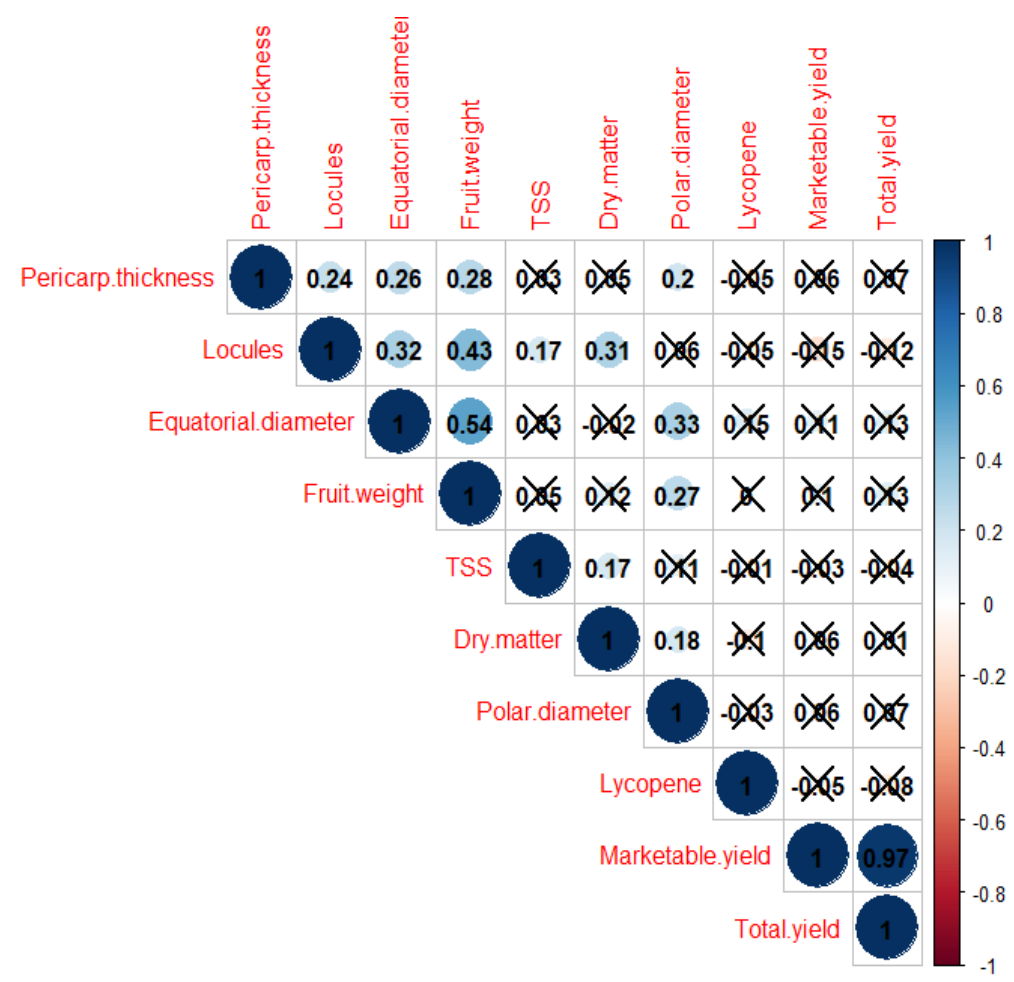

Figure 7. Pearson's correlation coefficients with significant values at $p<0.05$.

\section{Conclusions}

During the past few decades, breeding for tomato leaf curl virus resistance has been a major focus for the resistance breeding programs in tomato. Therefore, breeding efforts have been made to combine significant resistance to TLCV with important fruit quality and yield traits. The diallel mating design is a popular choice as it helps in the identification of parents with good GCA effects and hybrids with good SCA effects. Additionally, it provides the important information on gene action and inheritance of the traits. In this study, we evaluated morphological and biochemical traits of interest for tomato breeding under leaf curl virus pressure. The high diversity in the material was confirmed by GCA and SCA values for all traits. This showed the significance of both the additive and the non-additive effects in the inheritance of the traits evaluated. Furthermore, we have dissected the inheritance of total yield using the Bayesian approach. It was shown that total yield was more dependent on additive variance than the non-additive variance. Overall, this information will be useful to design and develop breeding programs aiming to improve TLCV resistance along with a respectable combination of important traits. The moderately resistant and high yielding parents (P4 and P9) and hybrids (H23, H42, and H49) could be used for resistance breeding in tomato.

Supplementary Materials: The following are available online at http://www.mdpi.com/2073-4395/8/8/153/s1, Table S1: The mean performance of parents and their hybrids for all studied characteristics. Table S2: Detailed data of specific combining ability of fifty-five one-way $\mathrm{F}_{1}$ hybrids.

Author Contributions: P.K. and M.S.D. conceived of and designed the project. M.S.D. supervised the study. P.K. performed the experiments. P.K. analyzed the data. P.K. wrote the paper. M.S.D. corrected the final draft. Both authors read and approved the final manuscript.

Funding: This research received no external funding.

Acknowledgments: P.K. is thankful to the anonymous reviewers for their careful reading of the manuscript and for providing insightful suggestions. P.K. would also like to thank Sarah Diane Turner for her help with the BayesDiallel package. Authors are also grateful to the members of advisory committee.

Conflicts of Interest: The authors declare no conflict of interest. 


\section{References}

1. Kalloo, G. Genetic Improvement of Tomato; Springer Science \& Business Media: Berlin, Germany, 2012; ISBN 978-3-642-84275-7.

2. Víquez-Zamora, M.; Vosman, B.; van de Geest, H.; Bovy, A.; Visser, R.G.; Finkers, R.; van Heusden, A.W. Tomato breeding in the genomics era: Insights from a SNP array. BMC Genom. 2013, 14, 354. [CrossRef] [PubMed]

3. Hossain, M.A.; Wani, S.H.; Bhattacharjee, S.; Burritt, D.J.; Tran, L.-S.P. Drought Stress Tolerance in Plants, Vol 1: Physiology and Biochemistry; Springer: Berlin, Germany, 2016; ISBN 978-3-319-28899-4.

4. Jacobsen, S.-E.; Jensen, C.R.; Liu, F. Improving crop production in the arid Mediterranean climate. Field Crop. Res. 2012, 128, 34-47. [CrossRef]

5. Jensen, C.R.; Battilani, A.; Plauborg, F.; Psarras, G.; Chartzoulakis, K.; Janowiak, F.; Stikic, R.; Jovanovic, Z.; Li, G.; Qi, X.; et al. Deficit irrigation based on drought tolerance and root signalling in potatoes and tomatoes. Agric. Water Manag. 2010, 98, 403-413. [CrossRef]

6. Gupta, S.K.; Thind, T.S. Disease Problems in Vegetable Production; Scientific Publishers: New Delhi, India, 2012; ISBN 978-93-86347-51-0.

7. Xu, C.; Sun, X.; Taylor, A.; Jiao, C.; Xu, Y.; Cai, X.; Wang, X.; Ge, C.; Pan, G.; Wang, Q.; et al. Diversity, distribution, and evolution of tomato viruses in China uncovered by small RNA sequencing. J. Virol. 2017, 91, 1-14. [CrossRef] [PubMed]

8. Picó, B.; Díez, M.J.; Nuez, F. Viral diseases causing the greatest economic losses to the tomato crop. II. The tomato yellow leaf curl virus-A review. Sci. Hortic. 1996, 67, 151-196. [CrossRef]

9. Saxena, S.; Tiwari, A.K. Begomoviruses: Occurrence and Management in Asia and Africa; Springer: Singapore, 2017; ISBN 978-981-10-5984-1.

10. Gaikwad, K.A.; Cheema, D.S.; Sharma, A.; Dhaliwal, M.S. Reactioofelitetomato (Solanumly copersicum L.) germplasm against tomato leaf curl virus disease. Acta. Hortic. 2011, 157-161. [CrossRef]

11. Moriones, E.; Praveen, S.; Chakraborty, S. Tomato leaf curl new delhi virus: An emerging virus complex threatening vegetable and fiber crops. Viruses 2017, 9, 264. [CrossRef] [PubMed]

12. Sharma, N.; Prasad, M. An insight into plant-Tomato leaf curl New Delhi virus interaction. Nucleus 2017, 60, 335-348. [CrossRef]

13. Picó, B.; Díez, M.J.; Nuez, F. Evaluation of whitefly-mediated inoculation techniques to screen lycopersicon esculentum and wild relatives for resistance to tomato yellow leaf curl virus. Euphytica 1998, 101, 259-271. [CrossRef]

14. Singh, R.K.; Rai, N.; Singh, M.; Saha, S.; Singh, S.N. Detection of tomato leaf curl virus resistance and inheritance in tomato (Solanum lycopersicum L.). J. Agric. Sci. 2015, 153, 78-89. [CrossRef]

15. Díez, M.J.; Nuez, F. Tomato. In Vegetables II; Handbook of Plant Breeding; Springer: New York, NY, USA, 2008; pp. 249-323, ISBN 978-0-387-74108-6.

16. Kaushik, P.; Andújar, I.; Vilanova, S.; Plazas, M.; Gramazio, P.; Herraiz, F.J.; Brar, N.S.; Prohens, J. Breeding vegetables with increased content in bioactive phenolic acids. Molecules 2015, 20, 18464-18481. [CrossRef] [PubMed]

17. Arias, R.; Lee, T.-C.; Logendra, L.; Janes, H. Correlation of lycopene measured by HPLC with the L* , $a^{*}, b^{*}$ color readings of a hydroponic tomato and the relationship of maturity with color and lycopene content. J. Agric. Food Chem. 2000, 48, 1697-1702. [CrossRef] [PubMed]

18. Palozza, P.; Simone, R.E.; Catalano, A.; Mele, M.C. Tomato lycopene and lung cancer prevention: From experimental to human studies. Cancers 2011, 3, 2333-2357. [CrossRef] [PubMed]

19. Wei, M.Y.; Giovannucci, E.L. Lycopene, Tomato Products, and Prostate Cancer Incidence: A Review and Reassessment in the PSA Screening Era. Available online: https:/ / www.hindawi.com/journals/jo/2012/ 271063/ (accessed on 1 April 2012).

20. Des Marais, D.L.; Hernandez, K.M.; Juenger, T.E. Genotype-by-environment interaction and plasticity: Exploring genomic responses of plants to the abiotic environment. Ann. Rev. Ecol. Evol. Syst. 2013, 44, 5-29. [CrossRef]

21. Beckles, D.M. Factors affecting the postharvest soluble solids and sugar content of tomato (Solanumly copersicum L.) fruit. Postharvest Biol. Technol. 2012, 63, 129-140. [CrossRef] 
22. Acharya, B.; Dutta, S.; Dutta, S.; Chattopadhyay, A. Breeding tomato for simultaneous improvement of processing quality, fruit yield, and dual disease tolerance. Int. J. Veg. Sci. 2018, 1-17. [CrossRef]

23. Panthee, D.R.; Perkins-Veazie, P.; Anderson, C.; Ibrahem, R. Diallel analysis for lycopene content in the hybrids derived from different colored parents in tomato. Am. J. Plant Sci. 2015, 6, 1483. [CrossRef]

24. Shattuck, V.I.; Christie, B.; Corso, C. Principles for Griffing's combining ability analysis. Genetica 1993, 90, 73-77. [CrossRef]

25. Griffing, B. Concept of general and specific combining ability in relation to diallel crossing systems. Aust. J. Biol. Sci. 1956, 9, 463-493. [CrossRef]

26. Hanson, P.M.; Licardo, O.; Hanudin; Wang, J.-F.; Chen, J. Diallel analysis of bacterial wilt resistance in tomato derived from different sources. Plant Dis. 1998, 82, 74-78. [CrossRef]

27. Kaushik, P.; Plazas, M.; Prohens, J.; Vilanova, S.; Gramazio, P. Diallel genetic analysis for multiple traits in eggplant and assessment of genetic distances for predicting hybrids performance. PLOS ONE 2018, 13, e0199943. [CrossRef] [PubMed]

28. Do Rêgo, E.R.; do Rêgo, M.M.; Finger, F.L.; Cruz, C.D.; Casali, V.W.D. A diallel study of yield components and fruit quality in chilli pepper (Capsicum baccatum). Euphytica 2009, 168, 275-287. [CrossRef]

29. Taggar, G.K.; Gill, R.S. Preference of whitefly, Bemisiatabaci, towards black gram genotypes: Role of morphological leaf characteristics. Phytoparasitica 2012, 40, 461-474. [CrossRef]

30. Toscano, L.C.; Boiça, A.L., Jr.; Leal, A.; Maruyama, W.I. Nonpreference of whitefly for oviposition in tomato genotypes. Sci. Agr. 2002, 59, 677-681. [CrossRef]

31. Wu, H.X.; Matheson, A.C. Analysis of half-diallel mating design with missing crosses: Theory and SAS program for testing and estimating GCA and SCA fixed effects. Silvae Genet. 2000, 49, 130-137.

32. Xiang, B.; Li, B. A new mixed analytical method for genetic analysis of diallel data. Can. J. For. Res. 2001, 31, 2252-2259. [CrossRef]

33. Greenberg, A.J.; Hackett, S.R.; Harshman, L.G.; Clark, A.G. A hierarchical bayesian model for a novel sparse partial diallel crossing design. Genetics 2010, 185, 361-373. [CrossRef] [PubMed]

34. Lenarcic, A.B.; Svenson, K.L.; Churchill, G.A.; Valdar, W. A general bayesian approach to analyzing diallel crosses of inbred strains. Genetics 2012, 190, 413-435. [CrossRef] [PubMed]

35. Turner, S.D.; Maurizio, P.L.; Valdar, W.; Yandell, B.S.; Simon, P.W. Dissecting the genetic architecture of shoot growth in carrot (Daucus carota L.) using a diallel mating design. Genes Genom. Genet. 2018, 8, 411-426. [CrossRef] [PubMed]

36. Banerjee, M.K. Kalloo Inheritance of tomato leaf curl virus resistance in Lycopersicon hirsutum f. Glabratum. Euphytica 1987, 36, 581-584. [CrossRef]

37. Sharma, O.P.; Mahajan, R.; Singh, S. Field reaction of some root-knot resistant tomato varieties and hybrids to tobacco mosaic and tobacco leaf curl viruses. Indian J. Mycol. Plant Pathol. 1984, 14, 148-150.

38. Maria Alda, L.; Gogoaşă, I.; Bordean, D.-M.; Gergen, I.; Alda, S.; Moldovan, C.; Niţă, L. Lycopene content of tomatoes and tomato products. J. Agroaliment. Proc. Technol. 2009, 15, 540-542.

39. Rodríguez, F.; Alvarado, G.; Pacheco, Á.; Crossa, J.; Burgueño, J. AGD-R (Analysis of Genetic Designs with R for Windows) Version 4.0. Available online: https:/ / data.cimmyt.org/dataset.xhtml?persistentId=hdl: 11529/10202 (accessed on 11 June 2015).

40. Wei, T.; Simko, V.; Levy, M.; Xie, Y.; Jin, Y.; Zemla, J. Corrplot: Visualization of a Correlation Matrix. Available online: https:/ / github.com/taiyun/corrplot (accessed on 17 October 2017).

41. Peterson, B.G.; Carl, P.; Boudt, K.; Bennett, R.; Ulrich, J.; Zivot, E.; Cornilly, D.; Hung, E.; Lestel, M.; Balkissoon, K.; et al. Performance Analytics: Econometric Tools for Performance and Risk Analysis. Available online: https:/ / github.com/braverock/PerformanceAnalytics (accessed on 2 March 2018).

42. Lapidot, M.; Ben-Joseph, R.; Cohen, L.; Machbash, Z.; Levy, D. Development of a scale for evaluation of tomato yellow leaf curl virus resistance level in tomato plants. Phytopathology 2006, 96, 1404-1408. [CrossRef] [PubMed]

43. Ambawat, S.; Sharma, P.; Yadav, N.R.; Yadav, R.C. MYB transcription factor genes as regulators for plant responses: An overview. Physiol. Mol. Biol. Plants 2013, 19, 307-321. [CrossRef] [PubMed]

44. Gaikwad, K.A.; Sharma, A.; Cheema, D.S. Molecular detection and characterization of leaf curl virus infecting tomato in punjab, India. Acta. Hortic. 2011, 153-156. [CrossRef] 
45. Lapidot, M.; Friedmann, M.; Lachman, O.; Yehezkel, A.; Nahon, S.; Cohen, S.; Pilowsky, M. Comparison of resistance level to tomato yellow leaf curl virus among commercial cultivars and breeding lines. Plant Dis. 1997, 81, 1425-1428. [CrossRef]

46. Pérez-De-Castro, A.; Campos, G.; Julián, O.; Dueñas, F.; Álvarez, M.; Martínez-Zubiaur, Y.; Díez, M.J. Evaluation under diverse conditions of a differential host reaction scale to tomato yellow leaf curl virus in tomato. Phytopathol. Mediterr. 2017, 56, 50-61. [CrossRef]

47. Fereres, A.; Peñaflor, M.F.G.V.; Favaro, C.F.; Azevedo, K.E.X.; Landi, C.H.; Maluta, N.K.P.; Bento, J.M.S.; Lopes, J.R.S. Tomato infection by whitefly-transmitted circulative and non-circulative viruses induce contrasting changes in plant volatiles and vector behaviour. Viruses 2016, 8, 225. [CrossRef] [PubMed]

48. Channarayappa, C.; Shivashankar, G.; Muniyappa, V.; Frist, R.H. Resistance of lycopersicon species to bemisiatabaci, a tomato leaf curl virus vector. Can. J. Bot. 1992, 70, 2184-2192. [CrossRef]

49. Farzane, A.; Nemati, H.; Aroiee, H.; Mirshamsi, A.; Vahdati, N. The estimate of combining ability and heterosis for yield and yield components in tomato (Lycopersicon esculentum Mill.). J. Biol. Environ. Sci. 2012, 6, 129-134.

50. Shalaby, T.A. Mode of gene action, heterosis and inbreeding depression for yield and its components in tomato (Solanumly copersicum L.). Sci. Hortic. 2013, 164, 540-543. [CrossRef]

51. Shankar, A.; Reddy, R.V.S.K.; Sujatha, M.; Pratap, M. Combining ability and gene action studies for yield and yield contributing traits in tomato (Solanumly copersicum L.). Helix 2012, 6, 431-435.

52. Govindarasu, P.; Muthukrishnan, C.R.; Irulappan, I. Combining-ability for yield and its components in tomato. Sci. Hortic. 1981, 14, 125-130. [CrossRef]

53. Dufera, J.T.; Mohammed, W.; Hussien, S.; Kumar, V. Genetic analysis for fruit yield and quality attributes in some processing and fresh market tomato genotypes. Int. J. Veg. Sci. 2018, 24, 227-235. [CrossRef]

54. Kumar, R.; Srivastava, K.; Singh, N.P.; Vasistha, N.K.; Singh, R.K.; Singh, M.K. Combining ability analysis for yield and quality traits in tomato (Solanumly copersicum L.). J. Agric. Sci. 2013, 5, 213-218. [CrossRef]

55. Bleeker, P.M.; Diergaarde, P.J.; Ament, K.; Guerra, J.; Weidner, M.; Schütz, S.; de Both, M.T.J.; Haring, M.A.; Schuurink, R.C. The role of specific tomato volatiles in tomato-whitefly interaction. Plant Physiol. 2009, 151, 925-935. [CrossRef] [PubMed]

56. Maluta, N.K.P.; Fereres, A.; Lopes, J.R.S. Settling preferences of the whitefly vector Bemisiatabaci on infected plants varies with virus family and transmission mode. Entomol. Exp. Appl. 2017, 165, 138-147. [CrossRef]

57. Crowley, J.J.; Kim, Y.; Lenarcic, A.B.; Quackenbush, C.R.; Barrick, C.J.; Adkins, D.E.; Shaw, G.S.; Miller, D.R.; de Villena, F.P.-M.; Sullivan, P.F.; et al. Genetics of adverse reactions to haloperidol in a mouse diallel: A drug-placebo experiment and Bayesian causal analysis. Genetics 2014, 196, 321-347. [CrossRef] [PubMed]

58. Lunt, K.A.; Roux, C.Z.; Blokpoel, I.; Booyse, M. Inheritance of flavour in six tomato (Lycopersicone sculentum) varieties. S. Afr. J. Plant Soil 1999, 16, 113-117. [CrossRef]

59. Pandiarana, N.; Chattopadhyay, A.; Seth, T.; Shende, V.D.; Dutta, S.; Hazra, P. Heterobeltiosis, potence ratio and genetic control of processing quality and disease severity traits in tomato. N. Z. J. Crop Hortic. Sci. 2015, 43, 282-293. [CrossRef]

60. Souza, L.M.D.; Paterniani, M.E.A.; Melo, P.C.T.D.; Melo, A.M.D. Diallel cross among fresh market tomato inbreeding lines. Hortic. Bras. 2012, 30, 246-251. [CrossRef]

61. Kumar, D.; Kumar, R.; Kumar, S.; Bhardwaj, M.L.; Thakur, M.C.; Kumar, R.; Thakur, K.S.; Dogra, B.S.; Vikram, A.; Thakur, A.; et al. Genetic variability, correlation and path coefficient analysis in tomato. Int. J. Veg. Sci. 2013, 19, 313-323. [CrossRef]

62. de Souza, L.M.; Melo, P.C.T.; Luders, R.R.; Melo, A.M. Correlations between yield and fruit quality characteristics of fresh market tomatoes. Hortic. Bras. 2012, 30, 627-631. [CrossRef]

63. Rao, E.S.; Kadirvel, P.; Symonds, R.C.; Ebert, A.W. Relationship between survival and yield related traits in Solanum pimpinellifolium under salt stress. Euphytica 2013, 190, 215-228. [CrossRef]

(C) 2018 by the authors. Licensee MDPI, Basel, Switzerland. This article is an open access article distributed under the terms and conditions of the Creative Commons Attribution (CC BY) license (http:/ / creativecommons.org/licenses/by/4.0/). 